\title{
Influencing Factors of Mobile Marketing among Young Malaysian Customers
}

\section{Mohammed Abdulellah Yousuf Saeed and Hussain Ali Bekhet}

${ }^{1}$ Department of Graduate Business School, Universiti Tenaga Nasional, Malaysia

${ }^{2}$ Department of Graduate Business School, Universiti Tenaga Nasional, Malaysia,

Correspondence Author: Mohammed Abdulellah Yousuf Saeed, Department of Graduate Business School, Universiti Tenaga Nasional, Malaysia E-mail: moham_faras78@hotmail.com

Received date: 12 June 2018, Accepted date: 4 September 2018, Online date: 13 September 2018

Copyright: (C) 2018 Mohammed Abdulellah Yousuf Saeed and Hussain Ali Bekhet, This is an open-access article distributed under the terms of the Creative Commons Attribution License, which permits unrestricted use, distribution, and reproduction in any medium, provided the original author and source are credited.

Abstract
The objective of the study is to examine the influential factors of mobile marketing among young Malaysian customers. This
study concentrates only on survey of young Malaysian mobile marketing consumers in response to behaviors of mobile
marketing adoptions from which the data is derived. 900 questionnaires were distributed. Out of this number, 602 were
complete and useable. Based on study results, apart from personalization; attitude, perceived usefulness, trust, and
permission plays important role in increasing young customers' intentions to use mobile marketing services. Perceived
usefulness, perceived ease of use, perceived entertainment and personal attachment significantly influenced young
customers' attitudes towards mobile marketing.

Key words: Mobile Marketing, Technology Acceptance Model, Malaysia.

\section{INTRODUCTION}

Mobile devices represent one of the fastest growing marketing communication platforms and different mobile devices are in widespread use by the new generation across the world (Billore\& Sadh, 2015). More people are adopting mobile device as their primary communication device since the development of mobile technology and internet services is tremendous now and the penetration rates of mobile phones have increased. Throughout the world, the number of mobile phone users increased to 4,228.3 million in 2014 and expected to reach 5,067.9 million by 2019 (eMarketer, 2016). These continuous developments in internet technology coupled with higher penetration rate of mobile phones created a new platform for marketing activities known as 'mobile marketing' (Wong et al., 2015). The number of individuals who used Internet between 2005 and 2017 increased sharply from one billion to more than 3.5 billion worldwide (Statista, 2018). Recent statistics show that, throughout the world, $54 \%$ of the population used mobile phone by the end of 2017 and smartphone users were expected to reach 2.39 billion during the same period (eMarketer, 2016).

In Malaysia, based on 2016's selective indicators issued by International Telecommunication Union (ITU), mobile-cellular telephone subscriptions per 100 inhabitants was 141.17 , active mobile-broadband subscriptions per 100 inhabitants was 91.7 , percentage of households with computer was 72.2, percentage of households with internet access was 76.9, and the percentage of individuals using the Internet was 78.8 (ITU, 2017). Moreover, according to the Table 1, Malaysia scored far better than Asia, Pacific region and rest of the world in relevant indicators which reflect a high level of competitiveness in the mobile market that provide promising potential.

Table 1: Malaysian ICT indicators.

\begin{tabular}{|c|c|c|c|}
\hline Key indicators for Malaysia (2016) & Malaysia & Asia \& Pacific & World \\
\hline Fixed-telephone sub. per 100 inhab. & 15.6 & 10.0 & 13.6 \\
\hline Mobile-cellular sub. per 100 inhab. & 141.2 & 98.9 & 101.5 \\
\hline Active mobile-broadband sub. per 100 inhab. & 91.7 & 47.4 & 52.2 \\
\hline Percentage of households with computer & 72.2 & 37.8 & 46.6 \\
\hline Percentage of households with Internet access & 76.9 & 45.5 & 51.5 \\
\hline Percentage of individuals using the Internet & 78.8 & 41.5 & 45.9 \\
\hline
\end{tabular}

Source: ITU, 2017

Despite the tremendous penetration rate of mobile phones worldwide, mobile users still show negative attitudes toward mobile marketing communications (Watson, McCarthy, \& Rowley, 2013). In Malaysia, mobile marketing is relatively at its early stages (Lee \& Wong, 2016). According to MCMC's survey (2017) only $48.8 \%$ of participants used online shopping in Malaysia. Moreover, based on Rakuten (2010) study, 71\% of Malaysian online shoppers tend to regret their 
Citation: Mohammed Abdulellah Yousuf Saeed and Hussain Ali Bekhet., Influencing Factors of Mobile Marketing among Young Malaysian Customers. Australian Journal of Basic and Applied Sciences, 12(9): 63-72. DOI: 10.22587/ajbas.2018.12.9.11

online purchases, $48 \%$ were disappointed due to mismatched expectations, $29 \%$ were dissatisfied with the poor product quality and 30\% of Malaysians did not complete their online purchases. Therefore, it is important to study the factors that enhance customers' intentions to use mobile marketing services.Furthermore,there is a need to improve the understanding of mobile marketing adoption drivers (Shankar et al., 2010; Billore\& Sadh, 2015) and to understand why and how consumers may want to participate in mobile marketing (Persaud \&Azhar, 2012).

This study concentrates only on surveying young Malaysian mobile marketing consumers in response to behaviors of mobile marketing adoptions from which the data is collected. This research has significant theoretical and practical contributions. From a theoretical perspective, research on mobile marketing is still in its infancy stage and most of the studies focused on developed counters. Little attention has been paid to study the mobile marketing in less-developed countries in Asian region (Al-alaket al., 2010; Yang\& Hyun-Joo, 2010). Therefore, this study adds to the literature by examining the factors that play important role in determining the customers' attitudes and intentions to adopt mobile marketing in Malaysia. From a practical perspective, the widespread adoption of mobile phones represents a huge marketing opportunity to reach and serve consumers anytime and anywhere. However, marketers must ensure that their mobile phone marketing strategies are not intrusive. The current study provides a thorough understanding of the factors that may enhance the participation of youth customers in Malaysian mobile advertising which could help in developing successful mobile marketing and advertising strategies.

\section{Literature Review:}

\subsection{Mobile Marketing:}

The evolution of mobile marketing has resulted in new and fashionable ways of marketing businesses while simultaneously working on cost reduction, increased profitability, and hi-tech image (Saeed et al., 2018; Tunsakul, 2011). Academic literature defines mobile marketing in several ways. For instance, Bauer et al., (2005) identified m-marketing as "using the mobile phone as a means of conveying commercial content to customers". According to Carroll et al. (2007) mobile marketing is "Using interactive wireless media to provide customers with time and location sensitive, personalized information that promotes goods, services and ideas, thereby generating value for all stakeholders". Barutçu (2008) extended the previous definition and described mobile marketing as "marketing activities and programs performed via mobile phone in mobile commerce".

Studies conducted for understanding the consumer behavior of mobile services and regarding the impacts of mobile marketing have substantially increased in the past decade. The research processes involved in mobile marketing has evolved over various stages. At the beginning, researchers mainly focused on categorization application opportunities of mobile marketing, future potential of mobile marketing for mobile consumer and technological development mechanisms of mobile marketing (Barnes and Eusebio, 2004). Subsequent researchers were concerned with the usage of mobile service applications including organizational factors that affect the adoption of mobile technologies in organizations (Abdulrahman et al., 2018; Baber \&Westmancott, 2004; Fang et al., 2005; Wong \& Hsu, 2008). They were also concerned with organizational factors that affect performance adoption of mobile technologies in organizations, (Dhar \& Chowdhury, 2014; Dhar \& Hoque, 2015; Gebauer\& Shaw, 2004; Peffers\&Tuunanen, 2005; Ngai et al., 2007). Further many expressed their concern with organizational factors that affect consumer preferences (Tsang et al., 2004; Chen, 2008; Jung et al., 2016) and consumers satisfaction (Liang \& Yeh, 2011).

Recent studies focused on the effect of context awareness of mobile technologies in an organizational setting (Tamminen et al., 2004; Kurkovsky et al., 2005; Luley et al., 2005; Liang \& Yeh, 2011). The focuses of those studies have also been contextual factors in organizational contexts on consumer behavior of mobile services (Barnard, et al., 2007; Mallat et al., 2009; Verkasalo, 2009). In fact, researches on user contexts are said to have been around for some time in consumer behavior research (Liang \& Yeh, 2011). For example, Csikszentmihalyi and Csikzentmihaly (1991) argued that consumer decisions are frequently affected by situational factors such as features of certain occasions, time restrictions, or task characteristics. Further, Mallat et al. (2009; Liang \& Yeh, (2011) confirmed that mobility and contextual elements play a very significant role in the adoption of mobile services.

Scholars have examined various combination of factors that affect adoption of mobile marketing from different perspectives. The current study employs several factors scattered in different studies in one framework under direct and indirect association. These factors are essential in determining the intention to adopt mobile marketing and rarely included in earlier studies. For example, entertainment has been identified as an important emotional factor contributing to the formation of consumers' attitudes towards advertising (Jung et al., 2016).

\subsection{Factors of Mobile Marketing:}

Mobile marketing adoption and acceptance are on the rise, but marketers have little ability to consistently generate profits without a clear understanding of the elements that drive consumer acceptance (Barutcu, 2008). A sizeable body of research evolved on mobile marketing in the recent years. Much of the research conducted in consumer behavior of mobile services aimed at developing models that incorporate individual-level characteristics, such as socio-demographics, motivations, traits and perceptions, social and cultural influences, and other consumer-based patterns to explain the adoption of mobile marketing and prediction of mobile consumer behavior (Varnali\&Toker 2010).

Many factors were examined in the literature that influences the adoption of mobile marketing from both consumer and organizational perspectives; however, there is much inconsistency in literature and are fragmented (Roach, 2009). A review of the literature shows many probable factors, that have been discussed earlier, influence SMS advertising acceptance such as personal attitudes, perceptions and tendencies (Junglas et al., 2008; Bhatti, 2015; Khalifa \& Shen, 2008), demographics (Bigne et al., 2005; Karjaluoto et al., 2008) social/peer influence (Kim et al.,2008; Rohm \& Sultan, 2006), acceptance of the mobile medium itself (Heinonen \& Strandvik, 2007), Wireless Service Provider (WSP), brand trust (Zhang \& Mao, 2008) and "ability to identify and utilize the individual consumer's purchasing behavior characteristics" (Yeh \& Lin, 2010). There are several factors that affect consumer intention to adopt mobile marketing. The conceptualization of determinant factors of behavioral intention to adopt mobile marketing and the relationships in previous studies are discussed.

\section{Attitude towards mobile marketing:}

Attitude towards mobile marketing is defined as the respondents' feelings and beliefs toward using their mobile phones to access information about the brands, purchasing products, or receiving incentives such as coupons. It relates to respondents' evaluation of both utilitarian and hedonic benefits of using their mobile phones for information search, promotions receipt, and purchase purposes (Gao et al., 2012). According to the Theory of Reasoned Action (Ajzen\&Fishbein, 1975), attitude precedes actual behavior and has been used as a key adoption determinant in user acceptance research (Taylor et al., 1995; Venkatesh et al., 2003).

\section{Perceived Usefulness:}

Perceived usefulness can be defined as the degree to which the use of technology produces desirable outcomes and benefits (Davis, 1989; Lu et al., 2010). In this study context, perceived usefulness refers to how consumers perceive using mobile marketing services will provide benefits to them in their daily lives. The importance of perceived usefulness as antecedent that determines behavioral intention to use like a computer system has been noted in prior studies (e.g. Venkatesh \& Davis, 2000). Previous studies supported the significant influence of Perceived usefulness on acceptance of mobile marketing (Pagani, 2004; Persaud et al., 2012).

\section{Privacy and Trust:}

Research related to mobile privacy has discussed spamming and privacy invasion as central issues related to consumers' willingness to receive mobile advertisements (e.g. Barnes \&Scornavacca, 2004; Grant \&O’Donohoe, 2007; Leppaniemi\&Karjaluoto, 2005). Privacy concerns often arise with new information technologies such as the web-enabled mobile technology that supports enhanced capabilities for collection, storage, use and communication of personal information ( $\mathrm{Lu}$ et al. 2003). The risk associated with mobile marketing is the loss of privacy of mobile phone users. Rather than maximizing benefits, people will try to minimize their risk (Bauer, et al., 2005). 
Also, Trust is an important factor which affects consumer decisions to adopt technologies such as e-commerce. Customers deals with the highly uncertain situation when carrying on commerce especially in the internet virtual environment and trust is one of the most effective uncertainty reduction methods (Suh\& Han2003). Trust is a complex and abstract concept with many different definitions across research areas and no consensus on its definition, how it is formed or how it affects behavior (Bahmanziari et al., 2009).

\section{Permission and Personalization:}

Permission is a key issue in mobile marketing (Leppaniemi\&Karjaluoto, 2005). Permission-based marketing means that consumers permit marketers to educate them on its products (Kavassalis et al., 2003). Permission have been considered as an integral part of marketing relationships to improve the loyalty of customers for a long period. In permission-based advertising, consumers voluntarily participate in the marketing activities by making an agreement between message senders and consumers (Ünal et al., 2011). Furthermore, Personalization is one of the main features of mobile marketing. There are many concepts and definition of personalization in marketing, but few of them focus on mobile marketing (Riecken, 2000). Personalization is the "ability to proactively tailor products and product purchasing experiences to tastes of individual consumers based on their personal and preference information" (Chellappa\& Sin, 2005). Personalization in general means "building customer loyalty by building a meaningful one-to-one relationship; by understanding the needs of each individual and helping to satisfy a goal that efficiently and knowledgeably addresses each individual need in a given context” (Riecken,2000).

Perceived Ease of Use:

Perceived Ease of use is one of the important factors of the Technology acceptance model (TAM). According to this model, perceived ease of use is an important behavioral belief that affects behavioral intentions to accept a new technology. Perceived ease of use can be defined as the perception that a particular system or application is easy to use (Davis, 1989). In the context of the study, perceived ease of use explains user's perception of the difficulty associated with using mobile marketing.

\section{Entertainment and Personal attachment:}

Entertainment is defined as the ability to fulfil an audience needs for aesthetic enjoyment, fun diversion, or emotional pleasure (Ducoffe, 1996). Entertainment is a significant factor for mobile-based marketing (Haghirian\&Madlberger, 2005). According to Haghirian et al., (2005), perceived entertainment of mobile advertising is not only related to attitude but also adds the perceived value of the advertisement by the customer. However, the construct personal attachment refers to the extent to which consumers seek to personalize their mobile phones with unique content, wallpapers, and ringtones as ways to present their phones as extensions of the selfGao et al., (2010). Personal attachment refers to the extent to which a mobile phone represents an integral part of an individual's life such that they not only use it $24 / 7$ but also considers themselves addicted (Rohm et al., 2012).

\section{Theoretical Framework:}

Based on the review of the existing literature on mobile marketing, the theoretical framework of the study was developed. It is primarily based on the technology acceptance model (TAM) (Davis, 1989; Davis, et al., 1989). Based on the literature review above, this study extends the technology acceptance model (TAM) by including another variable that is not originally included in the TAM model. Four factors were based on the original TAM model: perceived ease of use, perceived usefulness, attitudes towards use, intention to use. This study extends the model by including six important factors (See Figure 1).

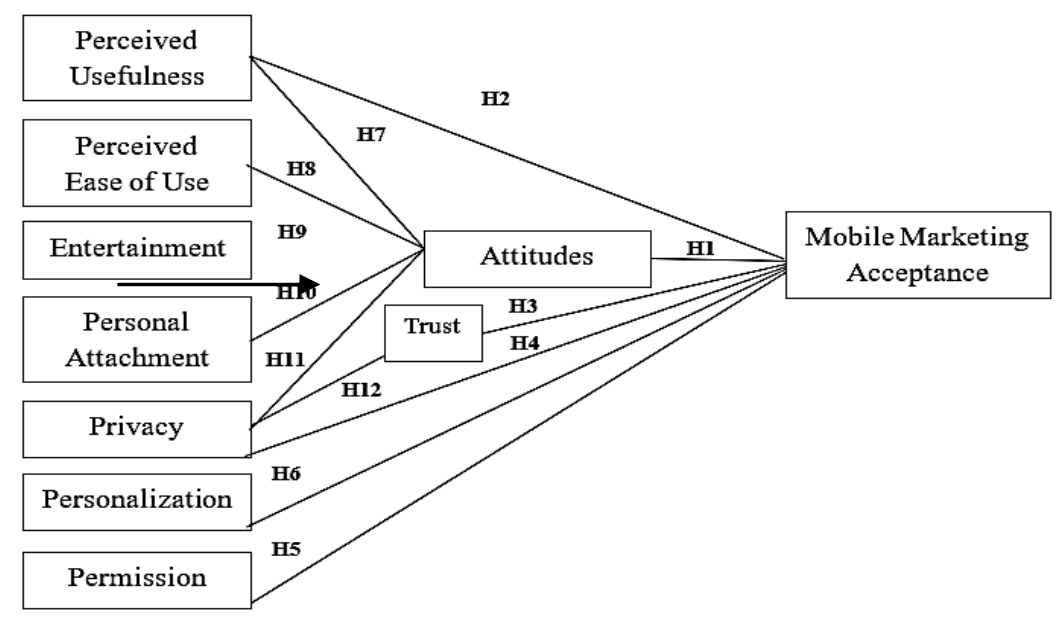

Fig. 1: Theoretical Framework.

The factors are entertainment, personal attachment, personalization, permission, privacy and trust. The model proposed that perceived usefulness, attitudes towards mobile marketing, permission, privacy and trust, and personalization are direct antecedents of mobile marketing acceptance. The model also suggests that perceived ease of use, perceived usefulness, entertainment, personal attachment and privacy are significantly related to customer's attitude towards mobile marketing.

Based on the discussion above and the theoretical framework of the study, the following hypotheses are formulated:

H1: There is a statistically significant relationship between attitude towards mobile marketing and intention to use mobile marketing services.

$\mathrm{H} 2$ : There is a statistically significant relationship between perceived usefulness and intention to use mobile marketing services

H3: There is a statistically significant relationship between privacy concern and intention to use mobile marketing services

H4: There is a statistically significant relationship between trust and intention to use mobile marketing services.

H5: There is a statistically significant relationship between permission and intention to use mobile marketing services.

H6: There is a statistically significant relationship between personalization and intention to use mobile marketing services

H7: There is a statistically significant relationship between perceived usefulness and attitude towards mobile marketing.

H8: There is a statistically significant relationship between perceived ease of use and attitude towards mobile marketing.

H9: There is a statistically significant relationship between entertainment and attitude towards mobile marketing.

H10: There is a statistically significant relationship between personal attachment and attitude towards mobile marketing.

H11: There is a statistically significant relationship between privacy concern and attitude towards mobile marketing.

H12: There is a statistically significant relationship between privacy concern and trust. 
Citation: Mohammed Abdulellah Yousuf Saeed and Hussain Ali Bekhet., Influencing Factors of Mobile Marketing among Young Malaysian Customers. Australian Journal of Basic and Applied Sciences, 12(9): 63-72. DOI: 10.22587/ajbas.2018.12.9.11

\section{Methodology:}

900 questionnaires were distributed. Out of this number, 627 were returned, giving a response rate of 63 percent. 25 questionnaires were found incomplete and removed from the data. Thus, a total of 602 responses were usable and used for subsequent analysis. Behavioral intention to use mobile marketing was measured using three items adapted from (Liao et al., 2008). Attitude towards mobile marketing was measured using four items adapted from (Taylor \& Todd, 1995). Perceived Usefulness was measured using five items adapted from (Pedersen, 2005). Perceived Ease of Use was measured using five items adapted from (Liao et al., 2008). Perceived Entertainment was measured using three items adapted from (Martí-Parreñoet al., 2013). Permission was measured using three items adapted from (Kautonen et al. (2007). The personal attachment was measured using three items adapted from (Gao et al., 2012). Personalization was measured using three items adapted from (Xu, 2006). Privacy concern was measured using three items adapted from (Gao et al., 2012). Trust was measured using four items adapted from (Tanakinjal, et al. 2010). Five-point Likert scale, ranging from $1=$ strongly disagree to $5=$ strongly agree was used to rate items. The data were first examined by using descriptive statistics such as frequencies, means and standard deviations. The purpose was to develop profiles of the total sample and to identify distributions of the variables. The hypotheses proposed in the study were tested using a structural equation modelling (PLS-SEM) procedure.Smart-PLS 3.0 software was used in this study to examine hypotheses and investigate the relationships among variables of the study.

\section{Results Analysis:}

Most respondents are female with $64.1 \%$ of the sample while male respondents represent $35.9 \%$ of the sample. In terms of age, sample subjects' age ranged from 15 to 27 years old. Most respondent's ages are between 20 and 24 years old with $54.8 \%$ of the sample. This significantly reflects the age group that is familiar with mobile marketing (Jayawardhena et al., 2009). 24.6\% of the sample ages between 15 to 19 years while $20.6 \%$ of the sample ages from 25 to 27 years old. In terms of ethnicity, most respondents are Malay with $60.1 \%$. Chinese respondents representing $26.4 \%$, Indian representing $11.8 \%$ and other races representing $1.7 \%$ of the sample. This result reflects, to some extent, the diversity of the Malaysian society. The following Table 2 shows the demographic analysis.

Table 2: Demographic Statistics.

\begin{tabular}{|c|c|c|c|}
\hline & Group & Frequency & Percent \\
\hline \multirow[t]{3}{*}{ Gender } & Male & 216 & 35.9 \\
\hline & Female & 386 & 64.1 \\
\hline & Total & 602 & 100.0 \\
\hline \multirow[t]{4}{*}{ Age } & $15-19$ years & 148 & 24.6 \\
\hline & $20-24$ years & 330 & 54.8 \\
\hline & 25-27 years & 124 & 20.6 \\
\hline & Total & 602 & 100.0 \\
\hline \multirow[t]{5}{*}{ Ethnicity } & Malay & 362 & 60.1 \\
\hline & Chinese & 159 & 26.4 \\
\hline & Indian & 71 & 11.8 \\
\hline & Others & 10 & 1.7 \\
\hline & Total & 602 & 100.0 \\
\hline
\end{tabular}

Cronbach's alpha and composite reliability (CR) are used to assess the reliability of constructs in this study (see Table 3). This is because it refers to the consistency among the variables in a summated scale, the indicators of the scale should all be measuring the same construct and thus be highly intercorrelated (Hair et al., 2010). Cronbach's alpha of all the factors exceeded the recommended value of 0.70 (Nunnally, 1978). Composite reliability of all the factors also exceeded the recommended value of 0.70 .

Furthermore, Discriminant validity was assessed by comparing square root of the AVEs with the correlation between that construct and the other constructs. As shown in Table 4, the square root of the AVEs exceeds the highest correlation between that construct and the other constructs, in support of discriminant validity (Chin 1998). Thus, it can be concluded that discriminant validity discriminant validity of the constructs is supported.

In addition, the structural equation modelling normally offers essentials links between the variables. It shows the specific details of the relationship between the independent or exogenous variables and dependent or endogenous variables (Hair et al., 2006; Ho, 2006). Evaluating the structural equation modelling helps focused firstly on the overall model fit, secondly on the size of the variables, thirdly on direction of results and fourthly on significance of the hypothesized parameter estimates, as shown by the one- headed arrows in the path diagrams (Hair et al., 2006). The final part involved is the confirmation of the structural equation modelling of the study which was based on the proposed relationship between the variables identified and assessed. In this study, the structural equation modelling has been estimated to examine the research hypothesis, by using PLS technique and bootstrapping with 1000 replications. In the structural model, the direct causal effects between the constructs were examined. These effects refer to the 12 hypotheses namely: H1, H2, H3, H4, H5, H6, H7, H8, H9, H10, H11 and H12. The values of $\mathrm{R}^{2}$ for Attitude Towards Mobile Marketing (ATT), Intention to Use Mobile Marketing (INT) and Trust (TR) were $0.126,0.433$ and 0.125 respectively (see Figure 2). This indicates, for example, 43 percent of variations in Intention to Use Mobile Marketing (INT) are explained by its six predictors (i.e, PU, ATT, PC, TR, PZ and PM). Overall findings showed that the $\mathrm{R}^{2}$ values satisfy the requirement for the 0.10 cut off value as recommended by (Patterson, 2013).

\section{Testing of the Hypotheses:}

The hypothesized relationships between constructs included in the model were assessed based on their respective standardized path coefficients and their critical ratios. The direct effects on each endogenous variable in the structural equation model and the results of hypotheses assessment are summarized in Table 5. 
Conclusion and Discussion:

Based on study results attitude, perceived usefulness, trust, and permission play important role in increasing young customers' intentions to use mobile marketing services. Perceived usefulness, perceived ease of use, perceived entertainment and personal attachment significantly influenced young customers' attitudes towards mobile marketing. However, privacy concern negatively influences young customers' attitudes and intentions towards mobile marketing. Interestingly, personalization was insignificant predictor of intention to use mobile marketing.Although the reasons for this finding are not clear, but some possible explanations might be discussed. To establish the ground for the explanation, it is important to mention that there is a "difference between statistical and practical significant" and obtaining insignificant statistical result for a variable does not imply that the factor is not importantlsignificant in reality (Filho et al., 2013). According to Filho et al., (2013) there are many reasons that may affect p-value result such sample size and accuracy of sampling method therefore, they argued that the researcher should not simply discard the variable only based on p-value.

Table 3: Convergent Validity for Measurement Model.

\begin{tabular}{|c|c|c|c|c|c|}
\hline$x^{2}+x^{2}$ & Item & $\begin{array}{l}\text { Factor } \\
\text { Loading }\end{array}$ & $\begin{array}{l}\begin{array}{l}\text { Average } \\
(\mathrm{AVE})^{\mathrm{a}}\end{array} \\
\text { Variance }\end{array}$ & $\begin{array}{l}\text { Composite Reliability } \\
(\mathrm{CR})^{\mathrm{b}}\end{array}$ & $\begin{array}{l}\text { Internal } \\
\text { Reliability } \\
\text { Cronbach Alpha }\end{array}$ \\
\hline \multirow{4}{*}{$\begin{array}{l}\text { Attitude Towards Mobile Marketing } \\
\text { (ATT) }\end{array}$} & ATT1 & 0.849 & \multirow[t]{4}{*}{0.673} & \multirow[t]{4}{*}{0.891} & \multirow[t]{4}{*}{0.840} \\
\hline & ATT2 & 0.775 & & & \\
\hline & ATT3 & 0.862 & & & \\
\hline & ATT4 & 0.791 & & & \\
\hline \multirow[t]{5}{*}{ Perceived Usefulness (PU) } & PU1 & 0.842 & \multirow[t]{5}{*}{0.692} & \multirow[t]{5}{*}{0.918} & \multirow[t]{5}{*}{0.890} \\
\hline & PU2 & 0.815 & & & \\
\hline & PU3 & 0.826 & & & \\
\hline & PU4 & 0.818 & & & \\
\hline & PU5 & 0.859 & & & \\
\hline \multirow[t]{5}{*}{ Perceived Ease of Use (PEU) } & PEU1 & 0.782 & \multirow[t]{5}{*}{0.608} & \multirow[t]{5}{*}{0.885} & \multirow[t]{5}{*}{0.842} \\
\hline & PEU2 & 0.830 & & & \\
\hline & PEU3 & 0.768 & & & \\
\hline & PEU4 & 0.741 & & & \\
\hline & PEU5 & 0.774 & & & \\
\hline \multirow[t]{3}{*}{ Perceived Entertainment (PE) } & PE1 & 0.845 & \multirow[t]{3}{*}{0.768} & \multirow[t]{3}{*}{0.909} & \multirow[t]{3}{*}{0.860} \\
\hline & PE2 & 0.853 & & & \\
\hline & PE3 & 0.929 & & & \\
\hline \multirow[t]{3}{*}{ Permission (PM) } & PM1 & 0.860 & \multirow[t]{3}{*}{0.767} & \multirow[t]{3}{*}{0.908} & \multirow[t]{3}{*}{0.850} \\
\hline & PM2 & 0.908 & & & \\
\hline & PM3 & 0.858 & & & \\
\hline \multirow[t]{3}{*}{ Personal Attachment (PA) } & PA1 & 0.829 & \multirow[t]{3}{*}{0.793} & \multirow[t]{3}{*}{0.920} & \multirow[t]{3}{*}{0.878} \\
\hline & PA2 & 0.918 & & & \\
\hline & PA3 & 0.920 & & & \\
\hline \multirow[t]{3}{*}{ Personalization (PZ) } & PZ1 & 0.882 & \multirow[t]{3}{*}{0.819} & \multirow[t]{3}{*}{0.932} & \multirow[t]{3}{*}{0.892} \\
\hline & PZ2 & 0.897 & & & \\
\hline & PZ3 & 0.936 & & & \\
\hline Privacy Concern (PC) & PC1 & 0.889 & 0.812 & 0.928 & 0.885 \\
\hline & $\mathrm{PC} 2$ & 0.925 & & & \\
\hline & PC3 & 0.889 & & & \\
\hline Trust (TR) & TR1 & 0.887 & 0.734 & 0.917 & 0.880 \\
\hline & TR2 & 0.866 & & & \\
\hline & TR3 & 0.861 & & & \\
\hline & TR4 & 0.812 & & & \\
\hline Intention to Use Mobile Marketing & INT1 & 0.905 & 0.758 & 0.904 & 0.841 \\
\hline & INT2 & 0.825 & & & \\
\hline & INT3 & 0.880 & & & \\
\hline
\end{tabular}

a: Average Variance Extracted = (summation of the square of the factor loadings)/\{(summation of the square of the factor loadings) $+($ summation of the error variances) $\}$.

${ }^{\mathrm{b}}$ : Composite reliability $=($ square of the summation of the factor loadings $) /\{$ (square of the summation of the factor loadings $)+($ square of the summation of the error variances)\}. 
Citation: Mohammed Abdulellah Yousuf Saeed and Hussain Ali Bekhet., Influencing Factors of Mobile Marketing among Young Malaysian Customers. Australian Journal of Basic and Applied Sciences, 12(9): 63-72. DOI: 10.22587/ajbas.2018.12.9.11

Having said that, it is important to mention that there is ongoing debate on the notion of personalization paradox. The general idea is that personalized marketing massages are more relevant to the consumer than non-personalized messages because of its ability to provide consumers with personalized information according to where they are and their needs. Thereby, persuading the receiver is not only to accept the message, but also to take some action, now or in the future, about goods, services and ideas (Saadeghvaziri\&Seyedjavadain, 2011). However, recent studies, found that personalization had its drawbacks. Aguirre et al. (2014) explained the issue as follows: "retailers gather data about customers' online behavior to develop personalized service offers. Greater personalization typically increases service relevance and customer adoption, but paradoxically, it also may increase customers' sense of vulnerability and lower adoption rates" (p.1).

Table 4: Correlations and Discriminant Validity.

\begin{tabular}{|l|l|l|l|l|l|l|l|l|l|l|}
\hline & ATT & INT & PA & PC & PE & PEU & PM & PU & PZ & TR \\
\hline ATT & 0.820 & & & & & & & & \\
\hline INT & 0.522 & 0.871 & & & & & & & \\
\hline PA & 0.209 & 0.180 & 0.890 & & & & & & \\
\hline PC & -0.144 & -0.264 & 0.000 & 0.901 & & & & & & \\
\hline PE & 0.222 & 0.201 & 0.254 & 0.018 & 0.877 & & & & \\
\hline PEU & 0.191 & 0.145 & 0.057 & -0.009 & 0.276 & 0.779 & & & & \\
\hline PM & 0.291 & 0.377 & 0.082 & -0.048 & 0.207 & 0.004 & 0.876 & & & \\
\hline PU & 0.236 & 0.229 & 0.339 & -0.073 & 0.244 & 0.250 & 0.058 & 0.832 & & \\
\hline PZ & 0.316 & 0.185 & 0.157 & 0.118 & 0.318 & 0.186 & 0.160 & 0.084 & 0.905 & \\
\hline TR & 0.310 & 0.502 & 0.102 & -0.354 & 0.168 & 0.011 & 0.425 & 0.088 & 0.083 & 0.857 \\
\hline
\end{tabular}

Note: Diagonals represent the square root of the average variance extracted while the other entries represent the correlations.

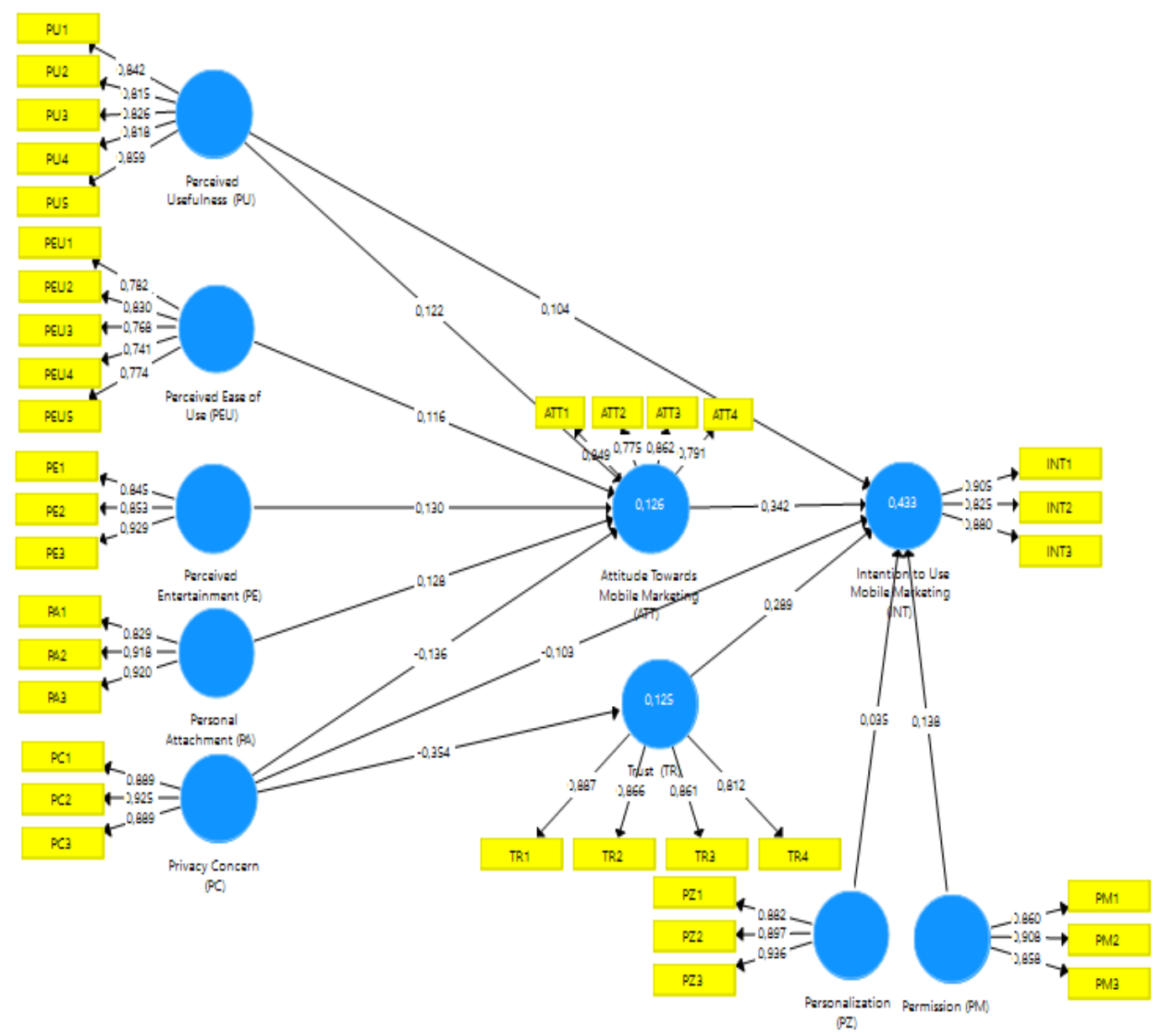

Fig. 2: Smart-PLS Structural Model for testing the direct effects of the variables.

Moreover, a very accurate personalized advertising may consideredby consumer as a sign of a privacy invasion (Grewal et al., 2016). The issues of security and privacy are crucial from Malaysia mobile market perspective where 83\% of Malaysian online shopper consider secure website and transaction "is the top criteria for online shopping" (Rakuten, 2010), and 74\% of Malaysians still hesitate to use mobile banking due to security concern (The Nielsen Company' report, 2016). Besides, $92 \%$ of Malaysian viewed online privacy as important (MCMC: Internet users survey, 2017), and only around half of the survey’s respondents believe that their service provider preserve confidentiality with regard to their personal data (MCMC: Hand phone users survey 2017). 
Citation: Mohammed Abdulellah Yousuf Saeed and Hussain Ali Bekhet., Influencing Factors of Mobile Marketing among Young Malaysian Customers. Australian Journal of Basic and Applied Sciences, 12(9): 63-72. DOI: 10.22587/ajbas.2018.12.9.11

Based on the above discussion, the insignificant result of personalization may be due to the limited sample size (602) or because of the oversensitivity of Malaysian consumers over their privacy. Therefore, retailers should address the personalization paradox issue and ensure the confidentiality of their personal data and practice transparent strategy in regard to collecting data procedure.

Table 5: Results of Hypothesized Direct Effects of the Constructs.

\begin{tabular}{|c|c|c|c|c|c|}
\hline Path Shape & Path Coefficient & Standard Deviation & T-value & P-value & Decision \\
\hline ATT $\rightarrow$ INT & $0.342^{* * * *}$ & 0.040 & 8.465 & 0.000 & H1: Supported \\
\hline $\mathrm{PU} \rightarrow \mathrm{INT}$ & $0.104^{* *}$ & 0.034 & 3.058 & 0.002 & H2: Supported \\
\hline $\mathrm{PC} \rightarrow \mathrm{INT}$ & $-0.103^{* *}$ & 0.035 & 2.972 & 0.003 & H3: Supported \\
\hline $\mathrm{TR} \rightarrow \mathrm{INT}$ & $0.289^{* *}$ & 0.042 & 6.955 & 0.000 & H4: Supported \\
\hline $\mathrm{PM} \rightarrow \mathrm{INT}$ & $0.138^{* *}$ & 0.040 & 3.452 & 0.001 & H5: Supported \\
\hline $\mathrm{PZ} \rightarrow \mathrm{INT}$ & 0.035 & 0.035 & 0.993 & 0.321 & H6: Rejected \\
\hline $\mathrm{PU} \rightarrow \mathrm{ATT}$ & $0.122^{* *}$ & 0.047 & 2.618 & 0.009 & H7: Supported \\
\hline $\mathrm{PEU} \rightarrow \mathrm{ATT}$ & $0.116^{* *}$ & 0.037 & 3.116 & 0.002 & H8: Supported \\
\hline $\mathrm{PE} \rightarrow \mathrm{ATT}$ & $0.130^{* *}$ & 0.038 & 3.403 & 0.001 & H9: Supported \\
\hline $\mathrm{PA} \rightarrow \mathrm{ATT}$ & $0.128^{* * * *}$ & 0.036 & 3.549 & 0.000 & H10: Supported \\
\hline $\mathrm{PC} \rightarrow \mathrm{ATT}$ & $-0.136^{* * *}$ & 0.038 & 3.577 & 0.000 & H11: Supported \\
\hline $\mathrm{PC} \rightarrow \mathrm{TR}$ & $-0.354^{* * *}$ & 0.039 & 9.074 & 0.000 & H12: Supported \\
\hline
\end{tabular}

Notes: *,**,*** the significance level at $0.05,0.01,0.001$ respectively.

Theoretically, this study contributes much to the literature. First, the study used well-established Technology Acceptance Model to develop and test a model of customer behavioral intention to use mobile marketing services in Malaysia. The study showed support to the validity and support to the robustness of the TAM model in predicting the young customer's attitudes and intentions towards mobile marketing. Second, the study integrated different perspectives to predict customer's attitudes and intentions towards mobile marketing. In addition to the main factors in the original TAM model, the study extended the TAM model by examining the importance of personal attachment, permeation and personalization which received little attention in previous studies especially in Malaysian context. Third, the study examined the role of privacy concern, trust and their interaction effect in predicting the customer's adoption of mobile marketing services.

However, this study has several practical implications. It is important for managers and marketers to identify various drivers and obstacles towards the acceptance of mobile marketing practices among consumers This study provides a deeper understanding about the Malaysian mobile internet service providers and marketers in terms of increasing adoption of mobile marketing services by explaining the intention of young consumers' to participate in mobile marketing services with different determinants adopted from the Technology Acceptance Model and using different factors which have not been examined before in Malaysia.

The study supported significant influence of intentions of young customers to use mobile marketing services. Therefore, the companies that practice mobile marketing needs to create positive attitudes towards the use of their mobile marketing services. This study suggests that perceived usefulness, personal attachment, and entertainment are important factors that have a significant influence of young customer's attitudes toward mobile marketing in Malaysia. Therefore, Malaysian mobile internet service providers and marketers need to show the benefits of mobile marketing services and its usefulness to customer. They need to continuously educate the consumers about the benefits and value. They also need to put more effort in making mobile marketing, a more entertaining and attractive one to the mobile device users. For example, they can develop entertainment-based mobile advertising such as using branded mobile video games or mobile games to attract young customer's attention.

\section{REFERENCES}

Aguirre, E., D. Mahr, D. Grewal, K. De Ruyter, M. Wetzels, 2014. Unraveling the personalization paradox: The effect of information collection and trustbuilding strategies on online advertisement effectiveness. Journal of Retailing, 91(1): 34-49.

Ajzen, Icek and Martin Fishbein, 1975. Belief, attitude, intention and behavior: An introduction to theory and research. Reading, MA: Addison-Wesley.

Al-alak, Basheer Abbass and Ibrahim AkramAlnawas, 2010. Examining the impact of mobile marketing on consumers' attitudes and purchase intentions. International Journal of Business and Management 5:28.

Arbuckle, James, 1997. Amos users' guide, version 3.6: Marketing Division, SPSS Incorporated.

Baber, C., O. Westmancott, 2004. September. Social networks and mobile games: The use of Bluetooth for a multiplayer card game. In International Conference on Mobile Human-Computer Interaction (pp: 98-107). Springer, Berlin, Heidelberg.

Bahmanziari, Tammy, Marcus D. Odom and Joseph, C. Ugrin, 2009. An experimental evaluation of the effects of internal and external e-Assurance on initial trust formation in B2C e-commerce." International Journal of Accounting Information Systems, 10: 152-170.

Barnard, L., J.S. Yi, J.A. Jacko, A. Sears, 2007. Capturing the effects of context on human performance in mobile computing systems. Personal and Ubiquitous Computing, 11(2): 81-96.

Barnes, N.G., S. Jacobsen, 2013. Adoption of social media by fast-growing companies: Innovation among the Inc. 500. Journal of Marketing Development and Competitiveness, 7(1): 11 . 
Citation: Mohammed Abdulellah Yousuf Saeed and Hussain Ali Bekhet., Influencing Factors of Mobile Marketing among Young Malaysian Customers. Australian Journal of Basic and Applied Sciences, 12(9): 63-72. DOI: 10.22587/ajbas.2018.12.9.11

Barnes, J., Stuart and Eusebio Scornavacca, 2004. Mobile marketing: the role of permission and acceptance. International Journal of Mobile Communications, 2: 128-139.

Barutcu, S., 2008. Consumers' attitudes towards mobile marketing and mobile commerce in consumer markets. Ege Academic Review, 8(1): 15-32.

Bauer, H., Hans, Tina Reichardt, Stuart J. Barnes and Marcus, M. Neumann, 2005. Driving consumer acceptance of mobile marketing: A theoretical framework and empirical study. Journal of electronic commerce research 6:181.

Bhatti, Tariq, 2015. Exploring factors influencing the adoption of mobile commerce. The Journal of Internet Banking and Commerce.

Bigne, Enrique, Carla Ruiz, and Silvia Sanz, 2005. The impact of internet user shopping patterns and demographics on consumer mobile buying behaviour.

Journal of Electronic Commerce Research, 6: 193.

Billore, Aditya and Ashish Sadh, 2015. Mobile advertising: A review of the literature. The Marketing Review 15:161-183.

Carroll, A., S.J. Barnes, E. Scornavacca, K. Fletcher, 2007. Consumer perceptions and attitudes towards SMS advertising: recent evidence from New Zealand. International Journal of Advertising, 26(1): 79-98.

Chellappa, R.K., R.G. Sin, 2005. Personalization versus privacy: An empirical examination of the online consumer's dilemma. Information technology and management, 6(2-3): 181-202.

Chen, L.D., 2008. A model of consumer acceptance of mobile payment. International Journal of Mobile Communications, 6(1): 32-52.

Chen, Yue, Xiangbin Yan, Weiguo Fan, and Michael Gordon, 2015. The joint moderating role of trust propensity and gender on consumers' online shopping

behavior. Computers in Human Behavior, 43: 272-283.

Chin, W., Wynne, 1998. The partial least squares approach to structural equation modeling.Modern methods for business research, 295: 295-336.

China, Thunderbird International Business Review, 54(2), 211-224.

Csikszentmihalyi, M. and M. Csikzentmihaly, 1991. Harper Perennial. New York.

Davis, F.D., 1989. Perceived usefulness, perceived ease of use, and user acceptance of information technology. MIS quarterly, 319-340.

Davis, F.D., R.P. Bagozzi, P.R. Warshaw, 1989. User acceptance of computer technology: a comparison of two theoretical models. Management science, 35(8): 982-1003.

Davis, D., Fred, 1989. Perceived usefulness, perceived ease of use, and user acceptance of information technology. MIS quarterly, 319-340.

Ducoffe, R.H., 1996. Advertising value and advertising on the web-Blog@ management. Journal of advertising research, 21.

Eastlick, M.A., S.L. Lotz, P. Warrington, 2006. Understanding online B-to-C relationships: An integrated model of privacy concerns, trust, and commitment. Journal of Business Research, 59(8): 877-886.

EMarketer Report, 2016. Worldwide retail ecommerce sales will reach \$1.915 trillion this year. URL: https://www.emarketer.com/Article/Worldwide-RetailEcommerce-Sales-Will-Reach-1915-Trillion-This-Year/1014369.

Fang, X., S. Chan, J. Brzezinski, S. Xu, 2005. Moderating effects of task type on wireless technology acceptance. Journal of Management Information Systems, 22(3): 123-157.

Figueiredo Filho, D.B., R. Paranhos, E.C.D. Rocha, M. Batista, J.A.D. Silva Jr, M.L.W.D. Santos, J.G. Marino, 2013. When is statistical significance not significant?. Brazilian Political Science Review, 7(1): 31-55.

Fornell, Claes and David F. Larcker, 1981. Structural equation models with unobservable variables and measurement error: Algebra and statistics. Journal of marketing research, 382-388.

Gao, T., F. Sultan, A.J. Rohm, 2010. Factors influencing Chinese youth consumers' acceptance of mobile marketing. Journal of Consumer Marketing, 27(7): 574-583.

Gao, Tao, Andrew J. Rohm, Fareena Sultan, and Suping Huang, 2012. Antecedents of consumer attitudes toward mobile marketing: A comparative study of youth markets in the United States and China. Thunderbird International Business Review, 54: 211-224.

Gebauer, J., M.J. Shaw, 2004. Success factors and impacts of mobile business applications: results from a mobile e-procurement study. International Journal of Electronic Commerce, 8(3): 19-41.

Grant, Ian and Stephanie O'Donohoe, 2007. Why young consumers are not open to mobile marketing communication. International journal of advertising, 26: $223-246$.

Grewal, D., Y. Bart, M. Spann, P.P. Zubcsek, 2016. Mobile advertising: a framework and research agenda. Journal of Interactive Marketing, 34: 3-14.

Gupta, P., J. Harris, 2010. How e-WOM recommendations influence product consideration and quality of choice: A motivation to process information perspective. Journal of Business Research, 63(9-10): 1041-1049.

Haghirian, P., M. Madlberger, 2005. Consumer attitude toward advertising via mobile devices-An empirical investigation among Austrian users. ECIS 2005 Proceedings, 44.

Haghirian, P., M. Madlberger, A. Tanuskova, 2005. Increasing advertising value of mobile marketing-an empirical study of antecedents. In System Sciences, 2005. HICSS'05. Proceedings of the 38th Annual Hawaii International Conference On (pp: 32c-32c). IEEE.

Hair, J.F., W.C. Black, B.J. Babin, R.E. Anderson, R.E. Tatham, 2006. Multivariate data analysis 6th ed. Uppersaddle River: Pearson Prentice Hall.

Hair, F., Joseph, William, C. Black, Barry, J. Babin, Rolph, E. Anderson and R.L. Tatham, 2010. "Multivariate data analysis (7th Eds.)." NY: Pearson.

Harris, M.A., R. Brookshire and A.G. Chin, 2016. Identifying factors influencing consumers' intent to install mobile applications. International Journal of Information Management, 36(3): 441-450. IEEE.

Heinonen, Kristina and Tore Strandvik, 2006. How do consumers react to mobile marketing? 3-3 in Mobile Business, ICMB'06. International Conference on:

Heinonen, K., T. Strandvik, 2007. Consumer responsiveness to mobile marketing. International Journal of Mobile Communications, 5(6): 603-617.

Ho, R., 2006. Handbook of univariate and multivariate data analysis and interpretation with SPSS. CRC Press.

International Telecommunication Union, 2017. Retrieved from https://www.itu.int/en/ITUTELECOM/Pages/world2016.aspx

Izquierdo-Yusta, A., C. Olarte-Pascual, E. Reinares-Lara, 2015. Attitudes toward mobile advertising among users versus non-users of the mobile internet.

Telematics and Informatics, 32(2): 355-366.

Jayawardhena, Chanaka, Andreas Kuckertz, HeikkiKarjaluoto and TeemuKautonen, 2009. "Antecedents to permission based mobile marketing: an initial examination." European Journal of Marketing 43:473-499.

Jung, J., S.W. Shim, H.S. Jin, H. Khang, 2016. Factors affecting attitudes and behavioural intention towards social networking advertising: a case of Facebook users in South Korea. International Journal of Advertising, 35(2): 248-265.

Junglas, I.A., N.A. Johnson, C. Spitzmüller, 2008. Personality traits and concern for privacy: an empirical study in the context of location-based services.

European Journal of Information Systems, 17(4): 387-402.

Karjaluoto, Heikki, HeikkiLehto, Matti Leppäniemi and ChanakaJayawardhena, 2008. "Exploring gender influence on customer's intention to engage permission- based mobile marketing." Electronic markets, 18: 242-259.

Kautonen, Teemu, HeikkiKarjaluoto, ChanakaJayawardhena and Andreas Kuckertz, 2007. "Permission-based mobile marketing and sources of trust in selected European markets." Journal of Systems and Information Technology 9:104-123.

Kavassalis, Petros, NtinaSpyropoulou, Dimitris Drossos, EvangelosMitrokostas, Gregory Gikas, and AntonisHatzistamatiou, 2003. "Mobile permission marketing: Framing the market inquiry." International Journal of Electronic Commerce 8:55-79.

Khalifa, Mohamed and Kathy Ning Shen, 2008. "Explaining the adoption of transactional B2C mobile commerce." Journal of enterprise information management, 21:110-124. 
Citation: Mohammed Abdulellah Yousuf Saeed and Hussain Ali Bekhet., Influencing Factors of Mobile Marketing among Young Malaysian Customers. Australian Journal of Basic and Applied Sciences, 12(9): 63-72. DOI: 10.22587/ajbas.2018.12.9.11

Kim, Gil Son, Se- Bum Park, and Jungsuk Oh, 2008. "An examination of factors influencing consumer adoption of short message service (SMS)." Psychology \& Marketing, 25: 769-786.

Krafft, M., C.M. Arden, P.C. Verhoef, 2017. Permission Marketing and Privacy Concerns-Why Do Customers (Not) Grant Permissions? Journal of Interactive Marketing, 39, 39-54.

Kurkovsky, S., V. Zanev, A. Kurkovsky, 2005. SMMART: using context-awareness in m-commerce. In Proceedings of the 7th international conference on Human computer interaction with mobile devices \& services (pp: 383-384). ACM.

Lee, W.O., L.S. Wong, 2016. Determinants of mobile commerce customer loyalty in Malaysia. Procedia-Social and Behavioral Sciences, $224: 60-67$.

Leppaniemi, Matti and HeikkiKarjaluoto, 2005. Factors influencing consumers' willingness to accept mobile advertising: a conceptual model. International Journal of Mobile Communications, 3:197-213.

Leppäniemi, Matti and HeikkiKarjaluoto, 2008. Mobile marketing: From marketing strategy to mobile marketing campaign implementation. International Journal of Mobile Marketing, 3: 50-61.

Liang, T.P., Y.H. Yeh, 2011. Effect of use contexts on the continuous use of mobile services: the case of mobile games. Personal and Ubiquitous Computing, 15(2): 187-196.

Liao, H., A. Chuang, A. Joshi, 2008. Perceived deep-level dissimilarity: Personality antecedents and impact on overall job attitude, helping, work withdrawal, and turnover. Organizational Behavior and Human Decision Processes, 106(2): 106-124.

Lin, J., B. Wang, N. Wang, Y. Lu, 2014. Understanding the evolution of consumer trust in mobile commerce: a longitudinal study. Information Technology and Management, 15(1): 37-49.

Lu, June, Chun-Sheng Yu, Chang Liu, and James E Yao, 2003. "Technology acceptance model for wireless Internet." Internet Research, 13: $206-222$.

Lu, Yaobin, Zhaohua Deng, and Bin Wang, 2010. "Exploring factors affecting Chinese consumers' usage of short message service for personal communication." Information Systems Journal, 20: 183-208.

Luley, P.M., L. Paletta, A. Almer, 2005. Visual object detection from mobile phone imagery for context awareness. In Proceedings of the 7th international conference on Human computer interaction with mobile devices \& services (pp: 385-386). ACM.

Mallat, N., 2007. Exploring consumer adoption of mobile payments-A qualitative study. The Journal of Strategic Information Systems, 16(4): 413-432.

Mallat, N., M. Rossi, V.K. Tuunainen, A. Öörni, 2009. The impact of use context on mobile services acceptance: The case of mobile ticketing. Information \& management, 46(3): 190-195.

Marsh, W., Herbert, Zhonglin Wen and Kit-Tai Hau, 2004. "Structural equation models of latent interactions: evaluation of alternative estimation strategies and indicator construction." Psychological methods, 9: 275.

Martí Parreño, J., S. Sanz-Blas, C. Ruiz-Mafé, J. Aldás-Manzano, 2013. Key factors of teenagers' mobile advertising acceptance. Industrial Management \& Data Systems, 113(5): 732-749.

Martí-Parreño, J., J. Aldás-Manzano, R. Currás-Pérez, I. Sánchez-García, 2013. Factors contributing brand attitude in advergames: Entertainment and irritation. Journal of Brand Management, 20(5): 374-388.

MCMC, 2017. Hand phone users survey. Retrieved from https://www.skmm.gov.my/skmmgovmy/media/General/pdf/HPUS2017.pdf

MCMC Internet users survey, 2017. Retrieved from: https://www.mcmc.gov.my/skmmgovmy/media/General/pdf/MCMC-Internet-Users-Survey-2017.pdf

Milne, G.R., M.E. Boza, 1999. Trust and concern in consumers' perceptions of marketing information management practices. Journal of interactive Marketing, 13(1): 5-24. $62-76$.

Ngai, E.W., T.E. Cheng, S. Au, K.H. Lai, 2007. Mobile commerce integrated with RFID technology in a container depot. Decision Support Systems, 43(1):

Nunnally, Jum, 1978. Psychometric methods. New York: McGraw-Hill.

Pagani, Margherita, 2004. Determinants of adoption of third generation mobile multimedia services. Journal of interactive marketing, 18: 46-59.

Pedersen, P.E., 2005. Adoption of mobile Internet services: An exploratory study of mobile commerce early adopters. Journal of organizational computing and electronic commerce, 15(3): 203-222.

Peffers, K., T. Tuunanen, 2005. Planning for IS applications: a practical, information theoretical method and case study in mobile financial services. Information \& Management, 42(3): 483-501.

Persaud, Ajax and Irfan Azhar, 2012. Innovative mobile marketing via smartphones: are consumers ready? Marketing Intelligence \& Planning 30:418-443.

Riecken, D., 2000. Personalized communication networks. Communications of the ACM, 43(8): 41-41.

Dhar, B.K., R. Chowdhury, 2014. Prospects and Problems of Green Marketing in Bangladesh, University of Science and Technology Annual, $20(6): 45-53$.

Dhar, B.K., M. Hoque, 2015. A Dynamic Practice of Human Resource Accounting for Financial Sustainability of Developing Nations: A Study on Bangladesh. International Journal of Business Society, 5(2): 14-20. DOI:10.30566/ijo-bs78.

Abdulrahman, A., A. Hesham, M.A.Y. Saeed, Ahmed, 2018. Attitude of Limkokwing Students toward Mobile Marketing in the Smartphone Era. International Journal of Business Society, 2(2): 7-14. DOI: 10.30566/2600-8254.2018.2.2.2

Rakuten, 2010. Smarter shopping survey infographic. Retrieved from https://www.digitalnewsasia.com/sites/default/files/files_upload/Infographic\%20\%20Rakuten\%20Smart\%20Shopping\%20Survey\%20\%20(Oct\%2010).pdf

Roach, G., 2009. Consumer perceptions of mobile phone marketing: a direct marketing innovation. Direct marketing: an international journal, 3(2): 124-138.

Rohm, A.J., T.T. Gao, F. Sultan, M. Pagani, 2012. Brand in the hand: A cross-market investigation of consumer acceptance of mobile marketing. Business Horizons, 55(5): 485-493.

Rohm, J., Andrew and Fareena Sultan, 2006. An exploratory cross-market study of mobile marketing acceptance. International Journal of Mobile Marketing, 1: 4-12.

Saadeghvaziri, F., S. Seyedjavadain, 2011. Attitude toward advertising: Mobile advertising vs advertising-in-general. European Journal of Economics, Finance and Administrative Sciences, 28(28), 104-114.

Saeed, M.A.Y., H.A. Hussain Ali Bekhet, B.K. Dhar, 2018. Constructing Model to Explore the Influence of Marketing Audit on Organizational Performance

- An innovative Arena of Marketing. Australian Journal of Basic and Applied Sciences, 11(15): 83-90.

Shankar, V., M.S. Yadav, 2010. Emerging perspectives on marketing in a multichannel and multimedia retailing environment.

Slade, E., M. Williams, Y. Dwivedi and N. Piercy, 2015. Exploring consumer adoption of proximity mobile payments. Journal of Strategic Marketing, 23(3): 209-223.

Statista, 2018. Retrieved from https://www.statista.com/

Suh, Bomil and Ingoo Han, 2003. Effect of trust on customer acceptance of Internet banking. Electronic Commerce research and applications, 1: 247-263.

Tamminen, S., A. Oulasvirta, K. Toiskallio, A. Kankainen, 2004. Understanding mobile contexts. Personal and ubiquitous computing, 8(2): 135-143.

Tanakinjal, Geoffrey H., Kenneth R Deans, and Brendan J Gray. 2010. Innovation characteristics, perceived risk, permissibility and trustworthiness in the adoption of mobile marketing. Journal of Convergence Information Technology 5:112-123.

Taylor, S., P.A. Todd, 1995. Understanding information technology usage: A test of competing models. Information systems research, 6(2): 144-176. 176.

Taylor, Shirley and Peter, A. Todd, 1995. Understanding information technology usage: A test of competing models. Information systems research, 6: 144-

The Nielsen Company, 2016. Mobile ecology: are Malaysian consumers ready for the new frontier of mobile banking \&payment?. Retrieved from http://www.nielsen.com/my/en/insights/news/2016/are-malaysian-consumers-embracing-the-virtual-wallet.html 
Tsang, M.M., S.C. Ho, T.P. Liang, 2004. Consumer attitudes toward mobile advertising: An empirical study. International journal of electronic commerce, 8(3): 65-78.

Tunsakul, Chaiyapat, 2011. An application of wavelets in control systems.

Ünal, S., A. Ercis, E. Keser, 2011. Attitudes towards mobile advertising-A research to determine the differences between the attitudes of youth and adults. Procedia-Social and behavioral sciences, 24: 361-377.

Varnali, K., A. Toker, 2010. Mobile marketing research: The-state-of-the-art. International journal of information management, 30(2): 144-151.

Venkatesh, Viswanath and Fred D Davis, 2000. A theoretical extension of the technology acceptance model: Four longitudinal field studies. Management science, 46: 186-204.

Venkatesh, Viswanath, Michael G. Morris, Gordon B. Davis and Fred, D. Davis, 2003. User acceptance of information technology: Toward a unified view.MIS quarterly, 425-478.

Verkasalo, H., 2009. Contextual patterns in mobile service usage. Personal and Ubiquitous Computing, 13(5): 331-342.

Wong, Choy-Har, Garry Wei-Han Tan, Boon-In Tan, and Keng-Boon Ooi., 2015. Mobile advertising: the changing landscape of the advertising industry. Telematics and Informatics, 32: 720-734.

Wong, Y.K., C.J. Hsu, 2008. A confidence-based framework for business to consumer (B2C) mobile commerce adoption. Personal and Ubiquitous Computing, 12(1), 77-84.

Watson, C., J. McCarthy, J. Rowley, 2013. Consumer attitudes towards mobile marketing in the smart phone era. International Journal of Information Management, 33(5): 840-849.

Xu, David Jingjun, 2006. The influence of personalization in affecting consumer attitudes toward mobile advertising in China. Journal of Computer Information Systems 47:9-19.

Yang, Kiseol and Hyun-Joo Lee, 2010. Gender differences in using mobile data services: utilitarian and hedonic value approaches. Journal of Research in Interactive Marketing, 4: 142-156.

Yeh, Jin-Tsann and Chyong-Ling Lin, 2010. Measuring the effectiveness of advertisements sent via mobile phone: Implications of the appeal, endorser, and involvement model and purchasing behavior. Social Behavior and Personality: an international journal, 38: 249-256. 805.

Zhang, J., E. Mao, 2008. Understanding the acceptance of mobile SMS advertising among young Chinese consumers. Psychology \& Marketing, 25(8): 787- 